\title{
FGFR3 NM_000142.4:c.746C>G
}

National Cancer Institute

\section{Source}

National Cancer Institute. FGFR3 NM 000142.4:C.746C>G. NCI Thesaurus. Code C128914.

A nucleotide substitution at position 746 of the coding sequence of the FGFR3 gene where cytosine has been mutated to guanine. 